УДК 32:001.891.3(075)

https://doi.org/10.34142/24130060.2019.18.2.10

\title{
ІНСТИТУТ ГРОМАДЯНСТВА СУСПІЛЬСТВА МОДЕРНУ: ПРОБЛЕМА РЕАЛІЗАЦІЇ В УКРАЇНІ
}

\author{
О. І. Кошкіна \\ Харківський національний університет будівництва і архітектури
}

Досліджується проблема реального змісту громадянства в Україні, ступеня реалізації в даному інституті західноєвропейської моделі національного громадянства. Розкриваються основні положення сучасної концепщіï національного громадянства, головні характеристики моделі громадянства епохи модерну та ії динаміка в умовах глобалізації. Дається авторська інтерпретація відповідності політико-юридичної форми $i$ змісту інституту громадянства в українських умовах. Показано, щчо оскільки політичні рішення (закони) щодо інституту громадянства як форми конкретного політичного явища приймаються відповідно до інтересів політичної еліти, його фактичний змістможе бути неадекватним декларованій формі. Відзначається, щореалізаціязахідноєвопейської моделі начіонального громадянства в межах однієї держави в умовах трансформаиії самої моделі, а також викликів і ризиків, пов'язаних із глобалізацією, тягне за собою інституиійний дисбаланс. Відмічено, щзо розвиток інституту громадянства неможливий без його підкріплення реальними можливостями рівноправного для всіх громадян доступу до реалізації прав власності та иентрів прийняття державних рішень.

Ключові слова: громадянство, підданство, наџія, наџіональна ідентичність, політична участь, державний суверенітет.

\section{ИНСТИТУТ ГРАЖДАНСТВА ОБЩЕСТВА МОДЕРНА:ПРОБЛЕМА РЕАЛИЗАЦИИ В УКРАИНЕ}

\section{О. И. Кошкина}

Исследуется проблема реального содержания гражданства в Украине, степени реализаџии в данном институте западноевропейской модели национального гражданства. Раскрываются основные положения современной концепции начионального гражданства, главные характеристики модели гражданства эпохи модерна и ее динамика в условиях глобализачии. Дается авторская интерпретация соответствия политико-юридической формы и содержания института гражданства в украинских условиях. Показано, что поскольку политические решения (законь) относительно института гражданства как формы конкретного политического явления принилаются в соответствии с интересами политической элиты, его фактическое содержание может быть неадекватным декларируемой форме. Отмечается, что реализация западноевропейской модели национального гражданства в пределах одного государства в условиях трансформащии самой модели, а также вызовов и рисков, связанных с глобализаџией, влечет за собой институциональный дисбаланс. Отмечено, что развитие института гражданства невозможно без его подкрепления реальными

(C) О. І. Кошкіна, 2019 
возможностями равноправного для всех граждан доступа $\kappa$ реализации прав собственности и иентрам принятия государственных решений.

Ключевые слова: гражданство, подданство, начия, начиональная идентичность, политическое участие, государственный суверенитет.

\section{INSTITUTE OF CIVIL SOCIETY OF MODERN: THE PROBLEM OF REALIZATION IN UKRAINE}

\section{O. Koshkina}

The problem of the real content of citizenship in Ukraine, the degree of realization in this institute of the Western European model of national citizenship is investigated. The basic provisions of the modern concept of national citizenship are revealed, the main characteristics of the modernity model of citizenship and its dynamics in the conditions of globalization. The author gives an interpretation of the correspondence of the political-legal for mend the content of the institution of citizenship in Ukrainian conditions. It is shown that since political decisions (laws) on the institution of citizenship as a form of a particular political phenomenon on are made in accordance with the interests of the political elite, its actual content may not bead equate to the declared form.

It is noted that the implementation of the Western European model of national citizenship within a single state in terms of transformation of the model itself, as well as the challenge sand risks associated with globalization, entails an institutional imbalance. It is noted that the development of the citizenship institute is impossible without its support by the real possibilities of equal access for all citizens to the realization of property rights and centers of decisionmaking.

For a more detailed analysis of the issues raised in the article, it is necessary to consider the institutional conditions for the existence of a Ukrainian citizen, to show the possibility of the existence of every Ukrainian as a private and public person, to identify the balance of freedom and equality in domestic political and legal institutions and practices. It is also proposed to further study the cultural and historical foundations of the political consciousness of contemporary Ukrainians, to compare their political culture and official discourse of European integration, to analyze the perception of their place in politics by the citizen.

Key words: citizenship, nationality, nation, national identity, political participation, state sovereignty.

Постановка проблеми. Перехід від традиційного суспільства 3 його станово-корпоративною моделлю державної організації до безстанового суспільства модерну з моделлю національної державності означав заміну інституту підданства (як легітимації суверенітету монарха) інститутом громадянства (який легітимізував суверенітет нації). У країнах Західної Європи і США громадянство та заснована на ньому політична система представницької демократії стали компенсаторним механізмом, що має нівелювати породжувану капіталістичною системою економічну нерівність індивідів. Протягом XIX-XX ст. інститут громадянства в західноєвропейських країнах еволюціонував у двох напрямах: розширення 
обсягу прав індивідів, визнаних громадянами, i поступового поширення громадянства на нові категорії населення (нижчі класи, жінок).

Однак в останній третині XX ст. під впливом тенденцій глобалізації та масової міграції модель національної держави почала зазнавати трансформацій як у напрямі обмеження суверенітету останньої на користь міжнародних структур, так і в напрямі обмеження деяких прав особистості, у тому числі у сфері власності. Особливо яскраво ці тенденції виявилися на пострадянському просторі, зокрема, в Україні, де ряд дослідників - як зарубіжних, так і вітчизняних - відмічають невідповідність реального обсягу громадянських прав українців західноєвропейським зразкам.

Аналіз актуальних досліджень. Витоки сучасної концепції громадянства можна прослідкувати в ідеях Т. Маршалла (1973), який виділяв три компоненти громадянства: власне «громадянського» (civic - основні особисті права і свободи), політичного і соціального. Ці три групи прав були об’єднані в єдиний статус громадянина. Однак обмеження певних економічних та соціальних прав у реальній практиці сучасного державотворення привернуло увагу дослідників до вивчення певних аспектів проблеми феномену громадянства. Представниками різних концептуальних підходів досліджувалися проблеми соціальної нерівності, формування нації, розвитку політичного змісту поняття «громадянин», формування громадянського суспільства, трансформації громадянства. Аналізу були піддані різні аспекти проблеми - через співвідношення 3 поняттями демократії (Головко, 2015; Хабермас, 1995), громадянства (Денисенко, 2015), національного суверенітету (Воронянський та ін., 2017). Досліджуючи режими громадянства різних країн, автори розвивали уявлення про специфічне співвідношення трьох груп прав у структурі громадянства в залежності від конкретного політичного контексту. Представники вітчизняної політичної науки акцентують увагу на проблемі специфіки еволюції нації і громадянства в українських умовах, а також на аналізі концептуальних основ сучасного громадянства (Воронянський та ін., 2017; 
Головко, 2015; Денисенко, 2015), поняттях політичної культури (Хангтингтон, 2004), корпоративного, транснаціонального та космополітичного громадянства (Зайончковський та Осіпов, 2019).

Мета статті - визначення реального змісту українського громадянства в контексті реалізації в ньому моделі західноєвропейського громадянства епохи модерну.

Виклад основного матеріалу. Уявлення про громадянство у вітчизняній політичній науці засновані на західноєвропейській парадигмі епохи модерну. У ній виділяється два аспекти існування громадянина: як об’єкта держави - підданого, пасивного члена політичної спільноти, і як політичного актора, що володіє конституційними правами участі в управлінні нацією-державою.

Громадянство формується в системі відносин громадянського суспільства і держави і включає кластери значень: легальний і соціальний статус; ознаки політичної ідентичності; фокусування культурної та політичної лояльності; вимога виконання зобов’язань (боргу) і очікування виконання прав; мірило правильної або належної поведінки в суспільстві (Marshall, 1950, p. 53-54). Дискусія про громадянство висвітлила різноманіття аспектів, значень і протиріч в даному феномені. Їх вирішення ми бачимо на шляху інтеграції основних аспектів феномену громадянина, цей шлях виводить на наступне розуміння громадянства.

Громадянство як підпорядкування, що фіксує статус приналежності, підданства індивіда державі, і громадянство як влада кожного члена даної держави, його активну «участь в пануванні» складають два граничних значення і вимірювання даного поняття (Воронянський та ін., 2017). Політична культура громадянина визначає можливість реалізації цих двох вимірів, що виражають різні історичні типи відносини держави i громадянина. Отже, громадянство як підданство - це статус індивіда в традиційних суспільствах, в сучасних державах він виступає в якості нижнього рівня статусу громадянина. Цей рівень характеризується 
підданською політичною культурою, пасивною політичною лояльністю як відчуттям підпорядкування i приналежності до конкретної держави i пасивною політичною поведінкою. Громадянство як політична участь включає в себе підданство, але складає вищий рівень явища: на основі формального статусу громадянина формуються громадянська політична культура, громадянська ідентичність, активна лояльність державі і активна політична діяльність (Денисенко, 2015). Дана концептуальна модель інституту громадянства i феномена громадянина закладена в основу Конституції України.

Однак в останні роки в Україні проявляється критичне осмислення копіювання (імітації) західних ліберально-демократичних інститутів, включаючи громадянство. «Ідеологія» антілібералізму породжена кількома факторами: відмовою від суверенітету національної держави на користь транснаціональних корпорацій та наднаціональних політичних структур, що викликало не лише адміністративне обмеження діяльності українських експортерів на міжнародних ринках, але й негативні міграційні процеси; розчаруванням населення в ефективності економічних і політичних реформ; «протестом проти принижень» через визнання іноземної культури вище власної; прагненням відновити національну самоповагу шляхом заперечення західних інститутів і цінностей в якості зразка для наслідування (Телеканал ZIK, 2017).

Крім того, певної еволюції зазнав і сам західноєвропейський інститут громадянства. Якщо в 1990-і рр. в Україні імпортувалася модерна модель національного громадянства, то сьогодні на Заході поряд із даною моделлю формуються моделі постнаціонального, космополітичного та глобального громадянства (Головко, 2015).

Звідси виникає кумулятивний ефект взаємодії різноспрямованих зовнішніх і внутрішніх політичних факторів. Важко реалізувати модель національного громадянства в межах однієї держави в умовах трансформації самої моделі, а також викликів і ризиків, пов’язаних із глобалізацією. 
Зрозумілі причини прихильності політичних еліт конструкції державного суверенітету. Однак у країнах СС існують і внутрішні протиріччя, викликані сталим політичним порядком, неефективністю їх власних еліт, відсутністю реальної націленості діяльності урядів на реалізацію прав і свобод громадян (Зайончковський та Осіпов, 2019).

Складність опису феноменів українського громадянина і громадянства полягає також у тому, що існують політичні та юридичні форми, які фіксуються найменуванням даних феноменів і представлені законами, відповідними західноєвропейської моделі. Однак зміст даних форм - різні аспекти онтології індивіда і його відносин з державою як сукупність умов, факторів і практик здійснення принципів і норм, закріплених в юридичній формі, - на нашу думку, відрізняється принциповою невідповідністю самим формам. За політичним i юридичним терміном «громадянин», який вважається калькою європейського терміна «сіtizen» i, як вважають, несе в собі європейську модель відносин індивіда і держави, реально ховається інший зміст, обумовлений системним відтворенням нерівномірності розподілу доходів і власності в Україні (Воронянський та Кулішенко, 2016), а відтак - і неможливістю реальної громадянської участі для більшості українців.

Саме сукупність аспектів, процесів і тенденцій у відносинах індивіда i держави в Україні повинна створювати (але не створює) умови і можливості для рядового індивіда бути учасником місцевого самоврядування та членом громадянського суспільства, що створює політичну спільність громадян націю - як носія державного суверенітету (Воронянський, 2012), бути особою, яка має право участі в управлінні державою. Громадянство юридична та політична форма, призначена для включення індивіда в громадянське суспільство і націю як основу національної держави. Але що заважає реалізації європейської моделі громадянина і громадянства в Українських умовах? Яке походження невідповідності форми реальному змісту феномена громадянина? 
Стійке співвідношення між формою і змістом соціального явища складається паралельно в ході поступової еволюції суспільства. Однак в сфері політики форма може бути додана змістом цілеспрямовано, як штучний ідеологічний конструкт, створений 3 запозичених елементів. Політичні рішення (закони) щодо форми конкретного політичного явища приймаються відповідно до інтересів політичної еліти (Воронянський, 2014). Тому форма може бути неадекватною фактичному змісту і навіть спотворювати його. Звідси постає гострота проблеми невідповідності найменування (терміна), що позначає форму, фактичному змісту явища (інституту). Паралельно повороту від ідей демократії до ідеї «правильності» нації відбувається повернення у взаємодіях держави з індивідом до традицій підданства в його архаїчному вигляді.

Терміни ж «громадянство» i «громадянин» стають лише засобами легітимації влади еліти всередині країни, а також інструментами демонстрації «прогресивного» зовнішньополітичного образу країни. Продовжуючи застосовувати терміни «громадянин» $\mathrm{i}$ «громадянство» номінально, правлячі еліти відкидають їх зміст як політичних феноменів, пов’язаних із здійсненням правової держави - принципами верховенства права, рівності членів держави перед законом та ін. Суть такого підходу до громадянства полягає в «позбавленні прав громадянства при збереженні обов’язків і самого статусу громадянина», тобто в створенні нової форми підданства (Хангтинтон, 2004, с. 252). Влада фактично відтворює домодернові традиції формування різних наборів прав і обов’язків для різних груп населення. Метою цих процедур і практик стає наділення індивіда обов’язками перед державою при обмеженні його прав, аж до їх часткового або повного позбавлення. Практичні дослідження приводять до висновків про те, що активне громадянство як повнота реалізації політичних прав громадянина й досі залишається лише декларативним принципом Конституції. В Україні не тільки не відбувається «перетворення населення в громадян», не формується політичне громадянське суспільство як форма 
виробництва політичної громадянськості (Центр політико-правових реформ, 2017), але законсервований процес формування середнього класу, масового «приватного індивіда» як носія цивільних прав, які $\epsilon$ основою прав політичних.

Висновки та перспективи подальших досліджень. Кінцевий наслідок дії цих факторів є низький рівень політичної участі і періодично виникають громадські протести. Інститути держави функціонують переважно в якості системи відсторонення масового громадянина від участі у визначенні цілей державного управління, а громадяни не стають значущими суб’єктами політики. Тому нинішній статус українських громадян можна визначити як номінальне (пасивне) громадянство, або підданство. Однак ми не виключаємо можливості реалізації європейської моделі громадянства та громадянина в Україні в майбутньому, але попередньо буде потрібно створити для цього комплекс фундаментальних політичних та інших умов. У кінцевому підсумку,розвиток інституту громадянства неможливий без його підкріплення реальними можливостями рівноправного для всіх громадян доступу до реалізації прав власності та центрів прийняття державних рішень.

Для більш детального аналізу піднятої в статті проблематики необхідно розглянути інституційні умови існування українського громадянина, показати можливості існування кожного українця в якості приватної i публічної особи, виявити співвідношення свободи і рівності у вітчизняних політичних i правових інститутах і практиках. Також необхідне подальше вивчення культурно-історичних основ політичної свідомості сучасних українців, зіставлення їх політичної культури й офіційного дискурсу євроінтеграції, проаналізувати сприйняття громадянином його місця в політиці.

\section{ЛIТЕРАТУРА}

1. Воронянський, О.В. та Кулішенко, Т. Ю., 2016. Влада як системний елемент економічних відносин: механізм відтворюваності. Вісник Харківського національного технічного університету сільського господарства імені Петра Василенка, 174, с. 109-117. 
2. Воронянський, О.В., 2012. Політична трансформація в контексті проблеми перерозподілу ресурсів. Вісник Харківського національного університету імені В. H. Каразіна. Серія: Питання політології, 20 (1007), с. 51-57.

3. Воронянський, О.В., 2014. Політичні інститути: механізм формування в конкурентному середовищі. Сучасне суспільство: політичні науки, соціологічні науки, культурологічні науки, [online] 1, с. 15-28. Доступно: http://nbuv.gov.ua/UJRN/cuc_2014_1_4 [Дата звернення 14 Січень 2019].

4. Воронянський, О. В., Євсєєв, С. С., Журавльов, Ю. В. та Зайончковський, Ю. В. 2017. Національний суверенітет: украйнський вимір в контексті світової політичної думки. Харків: «Міськдрук», ХНТУСГ імені Петра Василенка; ХНУБА.

5. Головко, I. В., 2015. Базові детермінанти формування ліберально-демократичних процесів у трансформаційних суспільствах. Сучасне суспільство: політичні науки, соиіологічні науки, культурологічні науки, 2(8), с. 13-26.

6. Денисенко, І. Д., 2011. Модернізація України в контексті сучасних політичних досліджень та соціальних практик. Вісник СевНТУ. Серія : Політологія, 123, с. 8386.

7. Денисенко, I. Д., 2013. Сучасна теорія конфлікту: проблеми експлікації, демаркації, класифікації. Украӥнський соиіум, 3(46), с. 16-26.

8. Денисенко, І. Д., 2015. Теорія соціального простору: евристичний потенціал щодо соціально-політичних досліджень. Сучасне суспільство: політичні науки, сочіологічні науки, культурологічні науки, 2 (2), с. 27-37.

9. Зайончковський, Ю.В. та Осіпов, О.М., 2019. Неокорпоративізм в умовах глобалізації: досвід Західної Європи. Сучасне суспільство: політичні науки, соиіологічні науки, культурологічні науки, 2(16), с. 98-107.

10. Телеканал ZIK, 2017. Соціологи виміряли рівень довіри українців до влад. [online] (Останне оновлення 01 лютого 2017) Доступно: http://zik.ua/news/2017/02/01/sotsiology_vymiryaly_riven_doviry_ukraintsiv_do_vlady_1 035987 [Дата звернення 10 Січень 2019].

11. Хабермас, Ю. 1995. Гражданство и национальная идентичность. Демократия. Разум. Нравственность: московские лекции и интервью. Москва: Наука.

12. Хантингтон, С., 2004. Кто мыз Bызовы американской нащиональной идентичности. Москва: Транзиткнига.

13. Центр політико-правових реформ, 2017. Новини, напрямки діяльності. [online] Доступно: http://pravo.org.ua/ua/news/20872527-visnovok-schodo-proektu-viborchogokodeksu-ukrayini--3112-1-vid-2-geovtnya-2015-roku [Дата звернення 2 Березень 2019].

14. Marshall, T. H. 1950. Citizenship and Social Class and Other Essays. Cambridge: Cambridge University Press.

15. Marshall, T. H. 1973. Class, Citizenship, and Social Development. Westport: Greenwood Press.

\section{Інформація про автора}

Кошкіна Ольга Ігорівна - доцент кафедри суспільно-гуманітарних дисциплін Харківського національного університету будівництва та архітектури; e-mail: styader@gmail.com; ORCID: http://orcid.org/0000-0003-1123-5411.

Стаття надійшла до редакції: 04.03.2019 р. Прийнята до друку: 19.03.2019 р. 